\title{
An Analysis of Financing Scheme Effect on Non-Performing Financing Asset at Islamic Banks In Indonesia
}

\author{
Fitrian Aprilianto ${ }^{1^{*}}$ \\ ${ }^{1}$ Program Studi Ekonomi Syariah, Fakultas Agama Islam, \\ Universitas Muhammadiyah Malang \\ Jln. Raya Tlogomas, No. 246, Lowokwaru, Malang \\ *fitrian@umm.ac.id
}

DOI: https://doi.org/10.22219/jes.v5i1.11400

Check for updates

\begin{tabular}{|c|c|}
\hline & ABSTRACT \\
\hline $\begin{array}{l}\text { Kata Kunci: } \\
\text { Non-Performing } \\
\text { asset; Islamic } \\
\text { finance; } \\
\text { mudaraba; } \\
\text { musharaka; } \\
\text { murabaha; } \\
\text { ijarah. }\end{array}$ & $\begin{array}{l}\text { This research aims to identify the impact of financing contract } \\
\text { towards the risks confronted by Islamic banks measured by Non- } \\
\text { Performing Financing (NPF). The method of research using panel } \\
\text { data analysis. The data of this study utilize secondary data in the form } \\
\text { of monthly time series data in the period of January } 2014 \text { to December } \\
2017 \text { and cross section data from the two types of Islamic Banking } \\
\text { (Bank Usaha Syariah and Unit Usaha Syariah). The result indicates } \\
\text { that the financing scheme based on the empirical scheme of profit } \\
\text { sharing schemes, especially musyarakah, is proven to increase } \\
\text { financing risk. }\end{array}$ \\
\hline
\end{tabular}

Article Info:

Submitted:

01/12/2019

Revised:

16/02/2020

Published:

29/02/2020

This work is licensed under a Creative Commons Attribution-ShareAlike 4.0 International (CC BY-SA 4.0)

How to cite: Aprilianto, F. (2020). An Analysis of Financing Scheme Effect on Non-Performing Financing Asset at Islamic Banks In Indonesia. Falah: Jurnal Ekonomi Syariah, 5(1), 25-32. doi. https://doi.org/10.22219/jes.v5i1.11400 


\section{INTRODUCTION}

Islamic bank has a different characteristics of financing risk than that of conventional bank. The difference lies on the financing product characteristic. The financial products of Islamic Bank are distinguished by the contracts $(a q d)$ used, which each product have different risk level and financing policies have an effect on financing risk (Sundararajan \& Errico, 2002; Effendi et al, 2017). Profit and loss sharing (PLS) based contracts, such as mudharaba and musharaka, is known to have considerably high risk since banks are dealing with agency problems namely adverse selection and moral hazard (Khan \& Ahmed, 2001; Samad, Gardner \& Cook, 2005; Ascarya \& Yumanita, 2005; Iqbal \& Llewellyn, 2002). Furthermore, murabahah contracts generally faces different risk that is the inability of customer to pay their loan (Antonio, 2011).

Previous research have attempted to analyse the asymmetric information when Islamic banking developed mudharabah and musyarakah contracts. (Sadr \& Iqbal, 2000) in line with this, Khalil et al, (2002) indicating within the context of agency theory, PLS system appear to be inherently characterized by agency problems. Khan \& Ahmed (2001) stated other problems relate to institutional arrangements such as taxes, accounting systems, and audits that do not support the application of wider musyarakah contracts in Islamic banking. While Kettell, (2011), emphasize that since the revenue sharing system emphasizes the distribution of risks and benefits between lenders and borrowers when the loan is made. Further, According to Shamsuddin \& Ismail (2013), the ijarah scheme basically has similarities to murabahah financing. Financing with ijarah can also provide relatively certain benefits, because the expected return can be calculated and agreed the beginning of the contract, allowing ijarah financing to only bear a low risk (similar to murabahah) (Karim, 2004).

One of the risks in Islamic banking is the level of Non-Performing Financing (NPF), which becomes a problematic financing ratio for a bank. If the problematic financing increases, the risk of a decrease in profitability will also increase (Muhammad, 2005). In line whit this also stated by Ascarya (2008); Khan \& Ahmed (2001), they argued that the lack of use of profit-sharing systems in Indonesia Islamic banking was caused by internal and external problems. While Nasution \& Wiliasih (2007) explained that the increase in murabahah allocations actually affected the increase in NPF.

According to Muhammad (2005), higher FDR ratio indicates lower bank's liquidity capability, due to higher amount of funds for financing. Greater financing will increase the income and profit obtained by the bank. Setiawan \& Putri (2013) stated that the high distribution of third-party capital will have an impact on the increasing risk of failure. If FDR increases, the possibility of increasing NPF will be also triggered. While Antonio (2001) stated that the main cause of NPF lies was on the financing cancelation based on Indonesian Bank (BI) regulations elaborated in Circular Letter No. 12/11/DPNP/2010, it 
Vol. 5 No. 1 (2020)

ISSN (print): 2502-3918 | ISSN (online): 2502-7824

is stated that the amount of FDR reflects the liquidity of a healthy bank (which is $85 \%$ $110 \%$ ), and the maximum limit of FDR is $110 \%$, which if above the limit of Bank liquidity (bad category). On the other hand, Sukmana (2015) indicated that in the long run, the relationship between CAR and NPF depicted a significant and negative result. While Setiawan \& Putri (2013) indicated that ROA, FDR, inflation, interest rates and GDP were significantly influential. ROA was the highest coefficient affecting NPF while inflation was the smallest coefficient affecting NPF. Then, Kinasih (2013) stated that the financing policy relying on murabahah did not always reduce the level of financing risk, despite perception that murabahah was a financing scheme with a low risk risk profile.

However, among the previous research only focusing on the contract in Islamic banks, and also the Non-Performing Financing (NPF) in Islamic Bank and also the riskof Islamic Bank ini Impelemting profit-sharing. But lack to attempt the impact of financing contract toward Islamic bank risk, measured by NPF. Therefore, this research aims to identify the impact of financing contract towards Islamic bank risk measured by NonPerforming Financing (NPF) through mudaraba, musharaka, murabaha, and ijarah contracts.

\section{RESEARCH METHOD}

This research using panel data analysis which in the initial stage is conducted by estimating model parameters with three approaches (models) consisting of: pooled least square, fixed effect approach (fixed effect), and random effect approach. In this study, the regression model utilized is a fixed effect, with the following explanation (Widarjono, 2013).

Fixed effect is a model with different intercepts for the subject (cross section), but the slope of each subject does not change over time (Gujarati, 2012). The fixed effect method assumes the regression coefficient (slope) remains equal between individuals and times (Widarjono, 2013). The limitations of the Pooled Least Square model can be overcome by inserting a dummy variable to allow for intercept differences $(\alpha)$. Other coefficients remain similar to each type of the observed banks. The fixed effect method can be described as follows:

$\gamma_{i t}=\alpha+\beta X_{i t}+{ }_{\gamma} W 2_{t}+{ }_{\gamma} W 3_{t}+\cdots+\varepsilon_{i t}$

After estimating the regression model to determine the best model, the next step is performed to test using Chow Test. The significance test results are comparisons between the common effect and fixed effects models. If P Value (Prob> F) is <Alpha of 0.05 then $\mathrm{H} 1$ is accepted, meaning the best choice is fixed effect at the lowest prob $\mathrm{F}$ value in the output of fixed effect. The analysis results indicate the value of the Prob. F 
of 0.000 , due to the value of the Prob. $F<0.05$. Thus, the estimation model that is more appropriate is the fixed effect model.

The next performed method is the Hausman test. If the Chow test falls on the fixed effect model, then the next stage is determining the best model (between fixed and random effect). If $\mathrm{P}$ Value (Prob $>\mathrm{Chi} 2$ ) is <Alpha 0.05 then $\mathrm{H} 0$ is rejected which means the best choice is fixed effect. The Hausman test results indicate that the Prob value> chi2 cross section random is 0.0000 or less than Alpha 0.05. Thus, it can be concluded that the null hypothesis is rejected which means that more appropriate model is the fixed effect model. Based on the results of the chow test and hausman test, the fixed effect model is accepted. Thus, it is concluded that the model is more accurately applied to analyze the effect of financing schemes (the fixed effect model).

To analyze the effect of mudharabah, musyarakah, murabahah, ijarah and FDR on the NPF level of Islamic banking in Indonesia, this study utilizes time series data from 2014-01 to 2017-12 and cross section data of 2 types of Islamic banking. The following formula is applied in this study:

$$
U_{i t}=\alpha+\beta_{1} M U D_{i t}+\beta_{2} M U S_{i t}+\beta_{3} M U R_{i t}+\beta_{4} I J H_{i t}+\beta_{5} F D R_{i t} \varepsilon_{i t}
$$

While:

$\begin{array}{ll}\alpha & : \text { Intercept } \\ \beta 1-3 & : \text { Regression Coefficient } \\ \text { Uit } & : \text { Total NPF } \\ \text { MUDit } & \text { : Mudaraba Financing } \\ \text { MUSit } & : \text { Musharaka Financing } \\ \text { MURit } & : \text { Murabaha Financing } \\ \text { IJHit } & : \text { Pembiayaan Ijarah } \\ \text { FDRit } & : \text { Financing to deposit ratio } \\ \varepsilon & : \text { Error } \\ i & : \text { Cross section data of two types of Islamic Banking } \\ t & : \text { Time Series Data 2014-01 - 2017-12 }\end{array}$

\section{RESULT AND DISCUSSION}

The results indicated that the partial variables of musyarakah statistical test are significant for NPF Islamic banking. Musyarakah variable coefficient of 0.0395 indicates that every increase of IDR 1 trillion in musyarakah financing on average will increase NPF by $3.95 \%$. This is in accordance with the hypothesis and study conducted by Abusharbeh (2014) pointing out that there is a positively significant relationship between the financing of profit loss sharing (mudharabah and musyarakah contracts) and NPF 
Vol. 5 No. 1 (2020)

ISSN (print): 2502-3918 | ISSN (online): 2502-7824

rates. The risks faced in financing musyarakah contract deal with the possibility of losses as a result of the financed business or projects and the dishonesty of the customer.

Table 1. Result Analysis of Financing Scheme Effect on Non-Performing Financing Asset

\begin{tabular}{lccl}
\hline \multicolumn{1}{c}{ Variable } & Coefficient & P-Value & \multicolumn{1}{c}{ Interpretation } \\
\hline Mudaraba $\left(\mathrm{X}_{1}\right)$ & 0.01313 & 0.770 & Not Significant \\
\hline Musharaka $\left(\mathrm{X}_{2}\right)$ & 0.03948 & 0.000 & Positive Significant \\
\hline Murabaha $\left(\mathrm{X}_{3}\right)$ & -0.05983 & 0.000 & Negative Significant \\
\hline Ijarah $\left(\mathrm{X}_{4}\right)$ & 0.22657 & 0.000 & Positive Significant \\
\hline FDR $\left(\mathrm{X}_{5}\right)$ & -0.02294 & 0.001 & Negative Significant \\
\hline
\end{tabular}

The partial test results of murabahah variables are significant for NPF Islamic banking. Murabahah variable coefficient value of -0598334 means that every increase of IDR. 1 trillion on average will reduce NPF by $-5.98 \%$. These results are in line with study pointing out that there is a negative correlation between the financing of non-profit loss sharing, which is the murabahah agreement on the NPF level. Murabahah has the certainty of profit and income, both in terms of the amount and time of payment. Both parties involved between the bank and the customer are abble to draw predictions about payments times. The research of Ahmed \& Khan (2001) also assume murabahah contract scheme as a financing with the lowest risk rating. Murabahah scheme is considered simple in its management because the level of return from the murabahah scheme can be determined in value, allowing banks to draw cashflow expectations.

The partial test results of the ijarah variables are significant for NPF Islamic banking. The ijarah variable coefficient is 0.2270 , which means that every increase of IDR. 1 trillion in ijarah financing on average will increase NPF by $22 \%$. The existence of a high NPF value in ijarah financing occurred due to problem in financing of mining, heavy equipment and leasings. Most ijarah financing portfolios from sharia banking for sectors related to mining and commodities have a substantial portion.

The partial statistical test results of the FDR variable are significant for NPF Islamic banking. The FDR variable coefficient value is -0.0229 which means that every $1 \%$ increase in FDR on average will reduce the NPF by $-2.29 \%$. Therefore, the FDR variable has a significantly negative effect on NPF Islamic banking. Expansive bank policy in channeling financing does not always lead to an increase in NPF, due to the effectively and optimally channeled financing contractsto improve the performance of Islamic banks. These results are in line with the Poetry \& Sanrego (2011) which indicate that the financing channeled by Islamic banks has good quality; therefore, the expansion of financing by Islamic banking can increase returns and reduce NPF rates. 


\section{CONCLUSION}

Based on the findings, it is can be concluded that the financing scheme based on the empirical scheme of profit sharing schemes, especially musyarakah, is proven to increase financing risk. The perception that musyarakah is a financing scheme possessing a high-risk profile which can be proven in regression tests by using the fixed effect model. Then, the financing scheme that relies on empirical murabahah contracts is proven to reduce the level of financing risk, the perception that murabahah is a financing scheme that has a low risk profile which can be proven in regression tests by using the fixed effect model. On the other hand, the financing scheme that is based on the ijarah contract is empirically proven to increase the risk of financing. Although characteristically the ijarah contract has similarities with murabahah contracts considered to have low risks, these do not guarantee the low risk of the ijarah scheme.

However, this research has limited scope, where the analysis in this study is only performed on financing contract variables. This study does not directly test each risk in financing contract. Future studies are expected to be able to engage the risk variables of each contract, to obtain a more comprehensive answer regarding the risk of financing. In optimizing the revenue sharing scheme and ijarah, future study is expected to focus on microfinance as an effort to mitigate risks.

\section{REFERENCES}

Abusharbeh, M. T. (2014). Credit Risks and Profitability of Islamic Banks: Evidence from Indonesia Abusharbeh. World Review of Business Research, 4(3), 136-147. Retrieved from https://www.isfin.net/sites/isfin.com/files/credit_risks_and_profitability_of_isla mic_banks-_evidence_from_indonesia.pdf

Ahmed, H. \& Khan T. (2007). Risk Management in Islamic Banking. Handbook of Islamic Banking: Edward Elgar Publishing.

Antonio, M, S. (2001). Bank Syariah: Dari Teori ke Praktik. Jakarta: Gema Insani Press.

Ascarya \& Yumanita, D. (2005). Mencari Solusi Rendahnya Pembiayaan Bagi Hasil di Perbankan Syariah Indonesia. Buletin Ekonomi Moneter Dan Perbankan, 8(1), 743. https://doi.org/10.21098/bemp.v8i1.127

Ascarya. (2008). The Lack of Profit and Loss Sharing Financing in Indonesia Islamic Banks: Revisted. Proceeding International Symposium on the Analytic Hierarchy Process, 1-15. Retrieved from http://www.isahp.org/2009Proceedings/Final_Papers/5_Ascarya_REV_FIN.pdf

Effendi, J., Thiarany, U., \& Nursyamsiah, T. (2017). Non-Performing Financing (NPF) at Sharia Banking. Jurnal Penelitian Sosial Keagamaan, 25(1), 109-138. https://doi.org/10.21580/ws.25.1.1540. 
Vol. 5 No. 1 (2020)

ISSN (print): 2502-3918 | ISSN (online): 2502-7824

Gujarati, D. N. (2012). Dasar-Dasar Ekonometrika, Trans. Mangunsong. (II). Jakarta: Salemba Empat.

Iqbal, M. \& David T. L. (2002). Introduction in Islamic Banking and Finance New Perspectives on Profit-Sharing and Risk. Cheltenham: Edward Elgar Publishing Limited.

Karim, A. (2004). Bank Islam: Analisis Fiqh dan Keuangan. Jakarta: PT Raja Grafindo Persada.

Kettell, B. (2011). Introduction to Islamic Banking and Finance. West Sussex, United Kingdom: John Wiley \& Sons Ltd.

Khalil, A.A., Rickwood C. \& Murinde, V. (2002). Evidence on Agency-Contractual Problems in Mudarabah Financing Operations by Islamic Banks. Cheltenham: Edward Elgar Publishing Limited.

Khan, T. \& Habib, A. (2001). Risk Management on Analysis of Issues in Islamic Financial Industry. Islamic Research and Training Institute (IRTI): Islamic Depelopment Bank. Retrieved from http://www.iefpedia.com/english/wpcontent/uploads/2009/10/Risk-Management-An-Analysis-of-Issues-in-IslamicFinancial-Industry-by-Tariqullah-Khan-Habib-Ahmed.pdf

Kinasih, S. W. (2013). Pengaruh Profil Risiko Jenis Pembiayaan Terhadap Rasio Non Performing Financing Bank Syariah Di Indonesia. Theses. Departemen Akuntansi, Fakultas Ekonomi Universitas Indonesia

Muhammad. (2005). Manajemen Bank Syariah. Yogyakarta: UPPAMP YKPN.

Nasution, M. E. \& Wiliasih. (2007). Profit Sharing dan Moral Hazard Dalam Penyaluran Dana Pihak Ketiga Bank Umum Syariah di Indonesia. Jurnal Ekonomi dan Pembangunan Indonesia, 8(2), 105-129. https://doi.org/10.21002/jepi.v7i2.175

Poetry, Z. D. \& Sanrego, Y. D. (2011). Pengaruh Variabel Makro dan Mikro Terhadap NPL Perbankan Konvensional dan NPF Perbankan Syariah. Islamic Finance \& Business Review, 6(2), 79-104. http://dx.doi.org/10.30993/tifbr.v6i2.53

Sadr, K. \& Iqbal Z. (2000). Choice of Debt or Equity Contract and Asymetrical Information: An Empirical Evidence, Conference Papers, $4^{\text {th }}$ International Conference on Islamic Economics and Banking. Loughborough University, UK, August 13-15, 487-499.

Samad, A., Gardner, N. D., \& Cook, B. J. (2005). Islamic Banking and Finance in Theory and Practice: The Experience of Malaysia and Bahrain. The American Journal of Islamic Social Sciences, 22(2), 69-86. Retrieved from https://www.semanticscholar.org/paper/Islamic-Banking-and-Finance-inTheory-and-Practice-SamadGardner/e858272b7a1090c07fc76d540d0184dec16315b5

Setiawan, C. \& Putri, M. E. (2013). Non-Performing Financing and Bank Efficiency of Islamic Banks in Indonesia', Journal of Islamic Finance and Business Research, 2(1), 58-76. Retrieved from https://www.google.com/url?sa=t\&rct=j\&q=\&esrc=s\&source=web\&cd=5\&cad= rja\&uact=8\&ved=2ahUKEwjhmNn9_q_nAhW14HMBHe2HCGwQFjAEegQIA RAC\&url=https\%3A\%2F\%2Fosf.io\%2Fwvstk\%2Fdownload\&usg=AOvVaw01 Y85FUDaPyTJwqN8Ikjmw 
Shamsuddin, Z., \& Ismail, A. G. (2013). Agency Theory in Explaining Islamic Financial Contracts. Middle-East Journal of Scientific Research, 15(4), 530-545. https://doi.org/10.5829/idosi.mejsr.2013.15.4.2361

Siamat, D. (2005). Manajemen Lembaga Keuangan. Jakarta: Fakultas Ekonomi, Universitas Indonesia.

Sukmana, R. (2015). Determinants of Non Performing Financing in Indonesian Islamic Banks. IRTI Working Paper Series, the Islamic Research and Teaching Institute (IRTI).1436-1439. Retrieved from https://ideas.repec.org/p/ris/irtiwp/1436_003.html

Sundararajan, V., \& Errico, L. (2002). Islamic Financial Institutions and Products in the Global Financial System: Key Issues in Risk Management and Challenges Ahead. IMF Working Paper. https://doi.org/10.5089/9781451859775.001. Retrieved from https://www.imf.org/external/pubs/ft/wp/2002/wp02192.pdf

Wahyudi, I., et.al,. (2015). Risk Management for Islamic Banks: Recent Development from Asia and the Middle East. Singapore: John Wiley \& Sons Singapore Pte. Ltd. Retrieved from https://www.wiley.com/enus/Risk+Management+for+Islamic+Banks\%3A+Recent+Developments+from+ Asia+and+the+Middle+East-p-9781118734421

Widarjono, A. (2013). Ekonometrika: Pengantar dan Aplikasinya Disertai Panduan Eviews. UPP STIM YKPN, Yogyakarta. 